\title{
Capital Inflows and Capital Flight - Individual Countries Experience
}

\author{
Chander Kant \\ Seton Hall University
}

\begin{abstract}
This paper examines whether individual countries' data show that FDI inflows facilitate capital flight and whether capital flight occurs due to poor domestic investment climate or is it due to discriminatory treatment against residents' investment. Three capital flight measures are used. Although the relationships have the expected signs, the absolute magnitude of the relationship among the countries differs widely. Also, the three measures of capital flight analyzed do not give consistent results. Thus, the definition and concept of capital flight that is actually used matters. (JEL Classifications: F23, F34, G15)
\end{abstract}

\section{Introduction}

Foreign direct investment (FDI) is now the largest single source of external finance for developing countries. The other phenomenon concerning finance and development is capital flight. Kuczynski [1992] estimates there is about $\$ 300$ billion of capital abroad belonging to residents in Latin America (which is potentially available for the reverse flow). On the other hand,

* Correspondence Address: Chander Kant, Department of Economics, Seton Hall University, South Orange, NJ 07079. U.S.A. (Tel) 973-761-9281, (Fax) 973-761-9217.

(C1998 - Institute for International Economics, Sejong Institution. All rights reserved. 
Claessens and Naude' [1993] report that capital flight is more widespread than previously thought with non-Latin American countries constituting six of the ten countries having the largest average annual capital flight during 1981-91; and also comprising eight of the ten countries with the highest ratio of the stock of flight capital to either GDP or external debt stock.

In the case of private external borrowing guaranteed by governments, foreign debt and capital flight have been observed to have accumulated simultaneously. Kant [1996] examines whether FDI inflows, by increasing the availability of foreign exchange, similarly facilitate capital flight from developing countries; and whether the dominant cause of capital flight (FDI inflows) is general economic mismanagement (attractive investment climate), or is it discriminatory treatment against residents' capital (and favored treatment to FDI) ? ${ }^{1}$ The conclusions are that private inflows are always associated with a reduction in capital flight and policies that improve general investment climate (rather than give favored treatment to non-resident investment) will both encourage capital inflows and reduce capital flight.

However, the said analysis was separately performed for aggregated data for all developing countries in three geographical regions: East Asia and the Pacific, Europe and the Mediterranean, and Latin America and the Caribbean. A natural question arises whether the results are any different when data are disaggregated by individual countries and whether such analysis yields results not shown by the aggregate exercise. The purpose of this paper is to undertake such an analysis.

This paper is organized as follows. Section II below presents information on FDI inflows into developing countries, as well as discusses three measures and concepts of capital flight. Two alternative hypotheses alluded to above on the possible relationships of capital flight to FDI are empirically investigated for fourteen developing countries in Section III. Additional results revealed are reported and empirical implications for Asian developing countries are investigated. Summary and policy implications of the study are stated in the concluding section.

1. "Attractive investment climate" refers to macroeconomic conditions that favor longterm investment, whether by residents or non-residents. This is explained further below. 


\section{FDI, Capital Flight, and Their Possible Relationships}

Foreign direct investment in developing countries has only recently increased at high rates. Between 1970 to 1980 , it barely rose (from $\$ 3.7 \mathrm{~b}$. to $\$ 4.7 \mathrm{~b})$ while it declined by $4 \%$ annually during $1981-85$. However, during 1986-1990 foreign direct investment in developing countries increased by $17 \%$ annually, while since 1990 it has increased by 40,33, 47, 17, and 13 percent, respectively, for 1991 through $1995 .^{2}$

One of the questions foreign direct (and portfolio inflows) raise is whether they mark return of the flight capital held abroad by residents of developing countries. There are varying estimates of magnitude of these hoardings. As stated above, amount by just the Latin American residents has been estimated to be as high as $\$ 300$ billion 〈Kuczynski [1992]〉. Per the standard two-sector neoclassical growth model, the higher marginal product of capital in poor countries should induce capital inflow in these countries. ${ }^{3}$ The interest in capital flight by poor countries lies precisely because of its counter-intuitive nature.

There is no consensus in the literature on a single definition or concept of capital flight; and the exact amount of capital flight given by different measures/definitions varies markedly. Two main approaches to measure capital flight are direct and indirect. ${ }^{4}$ Under the former approach, specific variables that constitute capital flight are identified, and data are directly sought for these variables. This approach associates capital flight with one or more categories of short term capital outflows and views it as a rapid response to

2. For information contained in this and the preceding paragraph, see World Bank [1995] and UNCTAD [1994]. Foreign direct investment is the main form of alternative (as opposed to traditional) financing, i.e. a source of external finance for developing countries not guaranteed or intermediated by the public sector.

3. The non-standard view permits inefficiencies and imperfections in markets. Thus, Gertler and Rogoff [1990] show that (greater) capital market inefficiencies in poor countries may enable poor-country savers to enjoy higher returns abroad, even though under full information they would do better to invest locally.

4. Lessard and Williamson [1987] term these two approaches the balance of payments accounts approach and the residual approach, respectively. However, the terminology "direct and indirect approach" is preferred in this paper because the residual method also relies substantially on the balance of payments statistics. 
investment risks. The indirect approach takes capital flight as a residual of the following four balance of payments components: increase in debt owed to foreign residents, net inflow of foreign direct investment, increase in foreign exchange reserves and the current account deficit. The premise is that the first two inflows finance the latter two "outflows" so that any inability of the first two "sources of funds" to finance the latter two "uses of funds" is indicative of capital flight.

In addition, Dooley [1987] defines capital flight as the stock of claims on nonresidents that do not generate investment income receipts in the creditor country's balance of payments data. Capital flight is thus defined directly. But, there is no category or line in the balance of payments statistics which meets this definition directly. Instead, data for outflows motivated by the desire to place assets beyond the control of domestic authorities have to be computed in a very indirect manner. This method is described below. ${ }^{5}$

Dooley computes three measures of the total external position of developing countries considered. These measures are the recorded external claims, the total external claims (both recorded and unrecorded), and the corrected total external claims. Aggregate stock of recorded (private and official) claims on nonresidents - other than direct investment - is calculated from the cumulated balance-of-payments data. Stock of errors and omissions in the cumulated balance-of-payments accounts is taken as a proxy measure for unrecorded claims on non-residents. The sum of recorded and unrecorded claims gives us the total external claims.

The balance-of-payments statistics, however, appear to underestimate the aggregate accumulation of cross-border claims. For example, for the countries studied, nonresidents claims on residents as estimated from the balance-of-payments statistics were only about 60 percent as large as the amount of external debt estimated by the World Bank. A similar understatement is assumed for residents claims on nonresidents, and total external claims are scaled up by a corresponding factor to get corrected total external claims.

The next step is to express investment-income receipts as percentages of these three alternative measures of stocks of claims on nonresidents to get

5. Please see Dooley [1987] or Kant [1996] for details. 
calculated or implicit yields. Dooley [1987] observes that these yields are implausibly low in comparison to market yields, and suggests that investment income receipts as reported in the balance of payments data are systematically understated. To derive his numbers for capital flight, he divides the reported receipts by market yields to obtain market-yield equivalent capitalized values of actual investment-income receipts and then subtracts the result from corrected total external claims to get his measure of capital flight.

This paper examines the relationship of FDI inflows to capital flight using one direct measure, called here and by Claessens and Naude [1993] as Hot Money 3, one indirect measure, referred to by the name of its author Cline, and the Dooley measure (termed here as the hybrid measure). Hot Money 3 is obtained by adding the following lines of the International Monetary Fund's balance of payments statistics: errors and omissions, other shortterm capital, other sectors (i.e. excluding the official sector and money-center banks), and the portfolio investments in both bonds and corporate equity. The Cline measure is a variant of the basic residual measure. It is obtained by excluding the following from the basic residual measure: acquisition of short-term foreign assets by the banking system and monetary authorities, reinvested investment income earned on bank deposits (and other assets) already held abroad, and income from tourism and other border transactions.

During the debt crisis of 80 's, it was often feared that providing external funds to cash-starved developing countries could be futile if a large part of increased lending flows right back out in the form of capital flight. Erosion of debt inflows by capital flight is confirmed by Cuddington [1987] and Pastor [1990]. The main sources of external finance to developing countries in the 1990's are, however, non-guaranteed private inflows among which foreign direct investment is the most important. Kant [1996] examines whether FDI inflows, by increasing the availability of foreign exchange, similarly facilitate capital flight from developing countries; and whether the dominant cause of capital flight (FDI inflows) is general economic mismanagement (attractive macroeconomic-investment climate), or is it discriminatory treatment against residents' capital (and favored treatment to FDI)? The conclusions are that private inflows are always associated with a reduction in capital flight and policies that improve general investment conditions 
(rather than give favored treatment to non-resident investment) will both encourage capital inflows and reduce capital flight.

However, the said analysis was performed for aggregated data for all developing countries in three geographical regions: East Asia and the Pacific, Europe and the Mediterranean, and Latin America and the Caribbean. A natural question arises whether the results are any different when data are disaggregated by individual countries and whether such analysis yields results not shown by the aggregate exercise. The purpose of this paper is to undertake such an analysis.

\section{The Hypothesis and the Results}

There is an inconclusive debate in the literature whether push or pull factors have been primarily responsible for the recent upsurge in private capital flows to developing countries. Calvo, Leiderman, and Reinhart [1993] conclude that push factors like low interest rates and recession in major creditor countries explain about 30 to 60 percent of private capital flows to ten Latin American countries during January 1988 to December 1991. Chuhan, Claessens, and Mamingi [1993] find that internal variables explain about half of the bond and equity flows from the United States to six Latin American countries during 1988-92; for Asia, they conclude that internal factors account for about two-thirds of bond and equity flows into the region.

Edwards [1991] shows that there appears to be a strong link between economic fundamentals in a cross-section of developing countries and foreign direct investment there. Hernandez and Rudolph [1995] show that between 1972 and 1989, three-year government-bond-yield in industrial countries and private flows to all developing countries have moved in the same direction. Lastly, Calvo, Leiderman, and Reinhart [1995] concede that as OECD economies move towards recovery, external factors (like recession in creditor countries) will become less significant in generating capital flows to Latin America and Asia.

Till recently, private non-guaranteed capital flows to developing countries consisted mainly of FDI. For example, 1991, 1990, and 1989, respectively, were the first years in which significant portfolio inflows (as opposed to direct or inflows with some control over real activities by foreign investors) 
occurred in China, Korea, and Malaysia. On the other hand, Korea and Malaysia had non-insignificant direct inflows even in 1970, while China experienced similar inflows starting from $1976 .{ }^{6}$ For FDI over the nineteenyears-period considered in this paper, domestic factors are likely to be more important than external factors like low interest rates in the recessionary phases of business cycles in creditor countries.

However, even restricting ourselves to domestic factors, we may distinguish between general versus discriminatory domestic factors. General factors or broad investment climate is defined here as the macroeconomic conditions that determine the risk-adjusted rate-of-return of assets in a country. As discussed by Lessard and Williamson [1987], this investment climate approach cannot explain capital simultaneously leaving and entering the country. ${ }^{7}$ Per this approach, capital flight depends on the above exchangerate-adjusted rate-of-return attractiveness of foreign assets as compared to domestic assets. Assets in the host country are either more or less attractive than assets in the foreign country, so that flows in both directions do not take place. ${ }^{8}$ On the other hand, the discriminatory treatment approach can explain such simultaneous occurrence. In fact, this approach was specifically put forward to explain private foreign lending (implicitly or explicitly guaranteed by governments) co-existing with capital flight.

As discussed above, the major capital inflow to developing countries in the recent period is private foreign investment (not lending) where the foreign investor faces the additional risk of variability in the nominal value of his return. However, the relevant factors in the context of international lending (difficulty of foreign lenders [investors] to assess the solvency [profitability] of a particular private borrower [project] in a developing country, and far greater market failure about enforceability of contracts for interna-

6. This information has been taken from the individual country section of World Debt Tables, various issues.

7. Generally, rather than borrowing themselves from the private external market, governments were giving implicit or explicit guarantees to borrowings by private entities. As discussed above, Eaton [1987] argues that by guaranteeing external, but not internal, borrowings, governments encouraged round-trip flows in the form of capital flight.

8. This view emphasizes the rate of return motivation of international capital flows rather than the risk-diversification objective. 
tional lending [investment] than for domestic lending [investment]) are applicable to international private investment also. Therefore, private foreign investors may also require their investments to be guaranteed or at least favorably treated by government of a developing country. ${ }^{9}$

Suppose macroeconomic conditions improve. This may mean one or more of the following: lower inflation, lower fiscal deficit, lower public consumption proportion, higher saving, investment, or export proportion, greater exchange rate, inflation, or political stability, etc. Then, if foreign direct investment takes place and favorable investment climate approach holds, capital flight ought to decrease. On the other hand, if foreign direct investment results from a favored treatment of such investment (and discrimination against residents' investment) - rather than from a general improvement of macroeconomic conditions - FDI inflows are likely to be accompanied by continued and accelerated capital flight, and the relationship between the two can be expected to be positive.

Clearly, if the discriminatory treatment explanation overrides the first and FDI inflow occurs, a capital inflow of one kind is accompanied by an outflow of another so that the net effect of the inflow is minimal. In that case, specific policies like tax-amnesty, tax-treaty, offering foreign-currency-denominated domestic instruments and capital-control programs may be needed to restrain outflows of capital and to induce repatriation of flight capital. On the other hand, if the general investment climate explanation is dominant (and the relationship between capital flight and FDI inflows is negative), then policies which stimulate investment in general would also entice flight capital to return (or for capital flight to decrease) so that the effect of FDI inflow on the economy will be magnified. This question thus has important policy implications.

Empirical investigation of the questions posed earlier are now presented. ${ }^{10}$ The main sources of data are: the World Bank and the International Monetary Fund. The World Bank [1994] has recently computed estimates

9. In fact, many developing countries do offer favorable treatment like differential taxation, investment or exchange rate guarantees, and priority over resident claims in the event of a financial crisis to private foreign investment.

10. Admittedly, a signifncant part of capital outflows from developing countries (especially since 1985) consists of outward foreign direct investment (and a low-income coun- 
of capital flight for each of the above measures for the period 1974-92 for all developing countries. ${ }^{11}$ These data for four East Asian, six Latin American and the Caribbean and four countries from Europe, Central Asia and North Africa are used in this study. Those countries were chosen which give the most statistically significant results. These countries are China, Korea, Malaysia, Thailand, Argentina, Chile, Costa Rica, Jamaica, Mexico, Paraguay, Malta, Morocco, Portugal, and Turkey. Data on foreign direct investment for the same countries have been taken from the International Monetary Funds's Balance of Payments Statistics Yearbook. ${ }^{12}$

Our estimation method is contemporaneous correlation analysis. Correlation analysis rather than regression are used because we have no basis for hypothesizing that one of them - capital flight or FDI/portfolio inflow - is the independent (dependent) variable. Although we have stated above that the sign of co-movement conveys information about the reason for FDI inflow and capital flight, much further analysis would be needed to determine causality, and the exact transmission of the relationship between these variables. Nevertheless, simple measures of association provide a useful start. These associations are examined in turn for each of the three measures of capital flight discussed above.

Tables 1 and 2 present statistically significant contemporaneous correlation analysis results for the East Asian and the Latin American countries respectively, while Table 3 shows similar results for the four countries from Europe, Central Asia and North Africa.

For each capital flight measure, the first number gives the estimated sample correlation coefficient. The number in parenthesis gives the cumulated probability of the population correlation coefficient being greater than the absolute value of the sample correlation coefficient under the null hypothe-

try, China, is the most important developing-country-exporter of foreign direct investment). However, since only net FDI inflow (net of outflow) is taken as a source of funds, these outflows are not included in the Cline and Dooley measures. The direct measure, Hot Money 3, does not include outward FDI flows in its definition of capital flight.

11. Low and middle-income countries as defined by the World Bank are termed developing countries in this paper.

12. Data used in this analysis are available on a diskette from the author. 
Table 1

K-Flight and FDI Correlations for Selected East Asian Countries

\begin{tabular}{|l|c|c|c|c|c|}
\hline & China & Korea & Malaysia & Thailand & $\begin{array}{c}\text { East Asia \& the } \\
\text { Pacific }\end{array}$ \\
\hline Cline & & -0.53 & -0.71 & -0.97 & -0.76 \\
& & $(0.02)$ & $(0.00)$ & $(0.00)$ & $(0.00)$ \\
\hline \multirow{2}{*}{ Dooley } & -0.93 & & -0.62 & -0.92 & -0.84 \\
& $(0.00)$ & & $(0.00)$ & $(0.00)$ & $(0.00)$ \\
\hline \multirow{2}{*}{ Hot M3 } & +0.91 & -0.49 & -0.49 & -0.96 & -0.50 \\
& $(0.00)$ & $(0.03)$ & $(0.03)$ & $(0.00)$ & $(0.03)$ \\
\hline \multirow{2}{*}{ Mean } & & -0.51 & -0.61 & -0.95 & -0.73 \\
\hline
\end{tabular}

Note: The numbers in parenthesis indicate the significance level. Mean values for China are not reported because of reasons discussed in the text.

Table 2

K-Flight and FDI Correlations for Latin American Countries

\begin{tabular}{|l|l|l|l|l|l|l|c|}
\hline & Argentina & Chile & Costa Rica & Jamaica & Mexico & Paraguay & $\begin{array}{c}\text { Latin America } \\
\text { \& the Caribbean }\end{array}$ \\
\hline Cline & -0.77 & -0.50 & -0.85 & -0.83 & -0.63 & -0.84 & -0.72 \\
& $(0.00)$ & $(0.03)$ & $(0.00)$ & $(0.00)$ & $(0.00)$ & $(0.00)$ & $(0.00)$ \\
\hline \multirow{2}{*}{ Dooley } & -0.72 & -0.54 & -0.72 & -0.72 & -0.66 & -0.87 & -0.65 \\
& $(0.00)$ & $(0.02)$ & $(0.00)$ & $(0.00)$ & $(0.00)$ & $(0.00)$ & $(0.00)$ \\
\hline \multirow{2}{*}{ Hot M3 } & & & -0.55 & & -0.67 & -0.63 & -0.57 \\
& & & $(0.01)$ & & $(0.00)$ & $(0.01)$ & $(0.00)$ \\
\hline Mean & -0.75 & -0.52 & -0.71 & -0.78 & -0.66 & -0.78 & -0.65 \\
\hline
\end{tabular}

Note: The numbers in parenthesis indicate the significance level.

sis that the population correlation coefficient is zero. $5 \%$ level of significance is used to select the correlations presented.

The following conclusions can be drawn from these tables. Note these results are based on time series data from 1974-92, and cover countries having very varied economic policies and experiences. The first conclusion is that although the relationship is not borne out for all three measures of capital flight for all the fourteen countries, generally, FDI is statistically significantly and negatively related to capital flight. Thus, in general, FDI inflows 
Table 3

K-Flight and FDI Correlations for Countries in Europe \& North Africa

\begin{tabular}{|l|c|c|c|c|c|}
\hline & Malta & Morocco & Portugal & Turkey & $\begin{array}{c}\text { Europe \& the } \\
\text { Mediterranean }\end{array}$ \\
\hline Cline & -0.85 & -0.70 & -0.77 & -0.56 & -0.50 \\
& $(0.00)$ & $(0.00)$ & $(0.00)$ & $(0.01)$ & $(0.03)$ \\
\hline \multirow{2}{*}{ Dooley } & & -0.84 & -0.62 & -0.49 & -0.62 \\
& & $(0.00)$ & $(0.00)$ & $(0.03)$ & $(0.00)$ \\
\hline \multirow{2}{*}{ Hot M3 } & -0.55 & & -0.58 & -0.55 & -0.57 \\
& $(0.02)$ & & $(0.01)$ & $(0.01)$ & $(0.01)$ \\
\hline Mean & -0.7 & -0.77 & -0.66 & -0.53 & -0.58 \\
\hline
\end{tabular}

Note: The numbers in parenthesis indicate the significance level.

can be expected to reduce capital flight, and therefore have magnified effects on an economy. Further, the dominant reason for FDI inflow (and reduced capital flight) is an improvement in the general macroeconomicinvestment climate rather than specific policies favoring foreign investment (and discriminating against residents' investment).

As stated above, all three measures of capital flight do not give similar results. Excluding the special case of China to be discussed shortly, the Cline method gives the most consistent results followed by the Dooley measure. The Hot Money 3 measure does not show significant relationship for four out of the other thirteen countries studied: Argentina, Chile, Morocco, and Jamaica. Thus, in contrast to the region-based analysis presented in Kant [1996], when data are disaggregated into individual countries (even confining ourselves to developing countries for which most results were obtained) it matters which definition/concept of capital flight is used. Thus, it becomes important to either develop criteria to choose one out of the different measures of capital flight on an empirical basis or to have a consensus in the literature on a specific definition of a capital flight which is robust. Now, we present results from the principal components analysis for the fourteen countries. As discussed by Swoboda [1983] and Calvo, Leiderman, and Reinhart [1993], such analysis is convenient for searching for a common element (or a number of common elements) from a number of individual time series. Principal components are linear combinations of the original 
Table 4

Factor Loading and CPV for East Asian Countries

\begin{tabular}{|c|c|c|c|c|c|c|c|c|c|c|c|c|}
\hline \multirow[b]{2}{*}{$\begin{array}{l}\text { Capital } \\
\text { Flight Measures }\end{array}$} & \multicolumn{3}{|c|}{ China } & \multicolumn{3}{|c|}{ Korea } & \multicolumn{3}{|c|}{ Malaysia } & \multicolumn{3}{|c|}{ Thailand } \\
\hline & $\begin{array}{l}\text { Capital } \\
\text { Flight }\end{array}$ & FDI & $\mathrm{CPV}$ & $\begin{array}{l}\text { Capital } \\
\text { Flight }\end{array}$ & FDI & $\mathrm{CPV}$ & $\begin{array}{l}\text { Capital } \\
\text { Flight }\end{array}$ & FDI & CPV & $\begin{array}{l}\text { Capital } \\
\text { Flight }\end{array}$ & FDI & $\mathrm{CPV}$ \\
\hline Cline & 0.48 & 0.62 & 0.77 & -0.56 & 0.56 & 0.76 & -0.60 & 0.54 & 0.83 & -0.62 & 0.63 & 0.78 \\
\hline Dooley & -0.58 & 0.57 & 0.95 & -.055 & 0.55 & 0.75 & -0.59 & 0.53 & 0.81 & -0.61 & 0.66 & 0.73 \\
\hline Hot M3 & 0.58 & 0.57 & 0.95 & -0.55 & 0.59 & 0.74 & -0.57 & 0.55 & 0.75 & -0.62 & 0.63 & 0.78 \\
\hline
\end{tabular}

Note: The above table gives the factor loadings and the cumulative percentage of variance explained by the first principal components.

\section{Table 5}

\section{Factor Loading and CPV for Latin American Countries}

\begin{tabular}{|l|c|c|c|c|c|c|c|c|c|}
\hline \multirow{2}{*}{$\begin{array}{c}\text { Capital } \\
\text { Flight Measure }\end{array}$} & \multicolumn{4}{|c|}{ Argentina } & \multicolumn{3}{c|}{ Chile } & \multicolumn{3}{c|}{ Costa Rica } \\
\cline { 2 - 10 } & Capital & FDI & CPV & $\begin{array}{c}\text { Capital } \\
\text { Flight }\end{array}$ & FDI & CPV & $\begin{array}{c}\text { Capital } \\
\text { Flight }\end{array}$ & FDI & CPV \\
\hline Cline & -0.57 & 0.57 & 0.88 & -0.65 & 0.51 & 0.62 & -0.71 & 0.71 & 0.93 \\
\hline Dooley & -0.56 & 0.57 & 0.86 & -0.65 & 0.55 & 0.61 & -0.71 & 0.71 & 0.86 \\
\hline Hot M3 & -0.49 & 0.61 & 0.74 & -0.68 & 0.20 & 0.57 & -0.71 & 0.71 & 0.78 \\
\hline
\end{tabular}

\begin{tabular}{|l|c|c|c|c|c|c|c|c|c|}
\hline \multirow{2}{*}{$\begin{array}{c}\text { Capital } \\
\text { Flight Measures }\end{array}$} & \multicolumn{4}{|c|}{ Jamaica } & \multicolumn{3}{c|}{ Mexico } & \multicolumn{3}{c|}{ Paraguay } \\
\cline { 2 - 11 } & Flight & FDI & CPV & $\begin{array}{c}\text { Capital } \\
\text { Flight }\end{array}$ & FDI & CPV & $\begin{array}{c}\text { Capital } \\
\text { Flight }\end{array}$ & FDI & CPV \\
\hline Cline & -0.71 & 0.71 & 0.91 & -0.57 & 0.56 & 0.83 & -0.71 & 0.71 & 0.92 \\
\hline Dooley & -0.71 & 0.71 & 0.86 & -0.58 & 0.54 & 0.86 & -0.71 & 0.71 & 0.93 \\
\hline Hot M 3 & -0.71 & 0.71 & 0.72 & -0.57 & 0.57 & 0.83 & -0.71 & 0.71 & 0.81 \\
\hline
\end{tabular}

Note: ibid.

variables that explain increasingly higher proportions of total variance of those variables.

Tables 4 and 5 report the factor loadings and cumulative percentage of variance explained by the first principal component for each of the three capital flight measures discussed for the East Asian and Latin American 
Table 6

Factor Loading and CPV for Countries in Europe and North Africa

\begin{tabular}{|l|c|c|c|c|c|c|c|c|c|c|c|c|}
\hline & \multicolumn{3}{|c|}{ Malta } & \multicolumn{3}{c|}{ Morroco } & \multicolumn{3}{c|}{ Portugal } & \multicolumn{3}{c|}{ Turkey } \\
\hline $\begin{array}{c}\text { Capital } \\
\text { Flight Measures }\end{array}$ & $\begin{array}{c}\text { Capital } \\
\text { Flight }\end{array}$ & FDI & CPV & $\begin{array}{c}\text { Capital } \\
\text { Flight }\end{array}$ & FDI & CPV & $\begin{array}{c}\text { Capital } \\
\text { Flight }\end{array}$ & FDI & CPV & $\begin{array}{c}\text { Capital } \\
\text { Flight }\end{array}$ & FDI & CPV \\
\hline Cline & -0.71 & 0.71 & 0.92 & -0.71 & 0.71 & 0.85 & -0.60 & 0.59 & 0.76 & -0.58 & 0.59 & 0.68 \\
\hline Dooley & -0.71 & 0.71 & 0.50 & -0.71 & 0.71 & 0.92 & -0.59 & 0.57 & 0.73 & -0.53 & 0.65 & 0.62 \\
\hline Hot M3 & -0.71 & 0.71 & 0.78 & -0.71 & 0.71 & 0.67 & -0.58 & 0.59 & 0.70 & -0.57 & 0.61 & 0.67 \\
\hline
\end{tabular}

Note: ibid

countries, respectively. The corresponding numbers for the four countries in Europe, Central Asia and North Africa are stated in Table 6.

As can be seen, findings of correlation analysis are confirmed by the results of the principal component analysis.

The unusual results for China are now discussed. Our results show that FDI inflows to China are positively related with one measure of capital flight and negatively with the other. Aside from reinforcing our earlier conclusion that the specific definition of capital flight used matters, these results also point to caution in interpreting capital inflows and outflows data for China. This is due to round-tripping of funds and investment from Hong Kong and Taiwan to China and vice-versa, and the complex web of relationships between often related business enterprises located in the coastal region of China and in Hong Kong and Taiwan. Our results suggest that such roundtripping of funds and interwoven relationships between enterprises may be substantial enough between some countries located close to each other to make the results unreliable.

Results for the other Asian countries - Korea, Malaysia, and Thailand are now discussed. First, only for one country, Korea, is a measure of capital flight not significantly related to FDI inflows. This is the Dooley measure. Second, the mean absolute value of the negative relationship differs among the three countries - it varies from .51 to $.95 .^{13}$ Thus, the magnification effect of FDI inflows is not uniform between countries. For example, in the case of Korea, a dollar of FDI inflow reduces capital flight by an average of 51 cents, while capital flight is reduced by 95 cents for every dollar of FDI 
inflow in Thailand. The evidence suggests that these differences can be somewhat ascribed to varying success these countries had in improving macroeconomic conditions.

All these three countries had high savings proportions during 1974-92. The average savings proportion (as a percentage of GDP) during this period was 29.8, 32.7, and 26.2 for Korea, Malaysia, and Thailand, respectively. The investment proportion was not very different in the beginning. However, from the average rate of 22.8 in Thailand during 1972-74, it increased by approximately 18 percentage points to 40.3 during 1990-92. For Korea, it increased by thirteen percentage points (from 24.3 to 37.3 ) while for Malaysia the increase was ten percentage points (from 24.0 to 34.0 ). ${ }^{14}$

On the other hand, the export and public consumption proportions for Korea in 1990-92 were unchanged from those in 1974-76 at 29.0 and 10.3, respectively. For Malaysia, the former increased by thirty percentage points (from 44.3 to 70.3 ) and the latter decreased by 2.3 percentage points (from 16.1 to 13.8 ), while for Thailand the corresponding changes were a 15 percentage points increase (from 20.1 to 35.2 ) and a .6 percentage points decrease (from 10.2 to 9.6). Lastly, although the variability of inflation was approximately the same for these three countries (coefficient of variation of the inflation rate varying from .68 for Malaysia to .72 for Thailand to .76 for Korea) the average annual inflation rate during this nineteen year period was 2.6 for Malaysia, 6.0 for Thailand, and 11.3 for Korea.

This evidence suggests that the overall macroeconomic conditions were better in Malaysia and Thailand than in Korea during this period. Malaysia had the lowest inflation rate and the greatest fall in the public consumption proportion. But, the investment and export proportions increased by the largest percentages in Thailand: the former increased by $76.8 \%$ (from 22.8 to 40.3) while the latter increased by $75 \%$ (from 20.1 to 35.2 ). Of the three economies, Thailand shows the best increase in international competitiveness and capital formation during this period.

13. Mean values for China are not computed because of reasons discussed in the previous paragraph.

14. The information in this and the next paragraph have been computed from International Einancial Statistics Yearbook [1995]. 


\section{Summary and Conclusions}

Foreign direct investment is now the largest single source of external finance for developing countries. Despite its increasing importance, relatively little attention has been given in the literature to its financial effects. This study uses individual countries' data to study one possible financial effect of FDI inflows: its relationship to capital flight.

In the case of private external borrowing guaranteed by governments, it has been found that $31 \%$ to $40 \%$ of such borrowings came right back as capital flight. This study examines whether individual countries' data show that FDI inflows similarly facilitate capital flight. The related question of the overriding cause of capital flight (as well as of FDI inflows), i.e. whether capital flight occurs due to poor domestic investment climate or is it due to discriminatory treatment against residents' investment is also examined with these data.

Relationship of FDI inflows to capital flight is examined using one direct measure, called Hot Money 3, one indirect measure, Cline, and the Dooley measure. Hot Money 3 is obtained by adding the following lines of the International Monetary Fund's balance of payments statistics: errors and omissions, other short-term capital, other sectors" (i.e. excluding the official sector and money-center banks), and the portfolio investments in both bonds and corporate equity. The following are excluded from the basic residual measure to get the Cline variant: acquisition of short-term foreign assets by the banking system and monetary authorities, reinvested investment income earned on bank deposits (and other assets) already held abroad, and income from tourism and other border transactions.

Estimates for these capital flight measures computed recently by the World Bank are used. Foreign direct and portfolio investment data are computed from the IMF's balance of payments statistics. The estimation method is principal component and contemporaneous correlation analysis.

In general, FDI inflows are associated with a reduction in capital flight. A related conclusion is that capital flight is primarily caused by general mismanagement and inefficiencies rather than by favorable treatment of foreign capital. This conclusion is quite consistent with the Gertler-Rogoff [1990] model cited above. Policies that reduce capital market frictions 
would encourage both capital inflows and reduce capital flight.

Using the individual countries' data, the only country for which we have ambiguous results is China. This could be due to the nature of capital inflows and outflows to and China which may have strong round-tripping of funds between China and Hong Kong and Taiwan. Also the extensive web of relationships between enterprises in coastal China and those in Taiwan and Hong Kong are somewhat unique in the developing world. Second, the absolute magnitude of the relationship among other thirteen countries differs widely - from a low of . 51 for Korea to a high of .95 for Thailand. Thus, a dollar of FDI inflow stems capital flight by 51 cents in Korea and by 95 cents in Thailand. The evidence suggests that these differences can be somewhat ascribed to varying success these countries had in improving macroeconomic conditions.

The export and public consumption proportions for Korea in 1990-92 were unchanged from those in 1974-76. Malaysia had the lowest inflation rate and the greatest fall in the public consumption proportion during this period. But, the investment and export proportions increased by the largest percentages in Thailand. Of the three economies, Thailand shows the best increase in international competitiveness and capital formation during this period. Thus, government policies that either increase competitiveness of an economy or foster capital formation shall have the greatest effect in stemming capital flight from developing countries.

Lastly, we find that when disaggregated country data are used, the three measures of capital flight analyzed do not give consistent results. Thus, the definition and concept of capital flight which is actually used matters. It points out the need to develop either an empirical test to choose between the different measures and concepts of capital flight, or to develop theoretically a widely acceptable and robust measure of capital flight from developing countries.

\section{References}

Calvo, G. A., Leiderman, L. \& Reinhart, C. [1993], "Capital Flows to Latin America: The Role of External Factors,” IMF Staff Papers 40; pp. 10851. 
Calvo, G. A., Leiderman, L. \& Reinhart, C. [1995], "Inflows of Capital to Developing Countries in the 1990s," Journal of Economic Perspectives 10; pp. 123-29.

Chuhan, P., Claessens, S. \& Mamingi, N. [1993], Equity and Bond Flows to Asia and Latin America: the Role of Global and Country Factors, World Bank Working Paper, No. 1160, The World Bank, Washington, D.C.

Claessens, S. \& Naude, D. [1993], "Recent Estimates of Capital Flight," World Bank Policy Research Working Paper No. 1186, The World Bank, Washington, D.C.

Cuddington, J. T. [1987], “Capital Flight," European Economic Review 31; pp. $382-88$.

Dooley, M. P. [1987], "Capital Flight, A Response to Differences in Financial Risks,” IMF Staff Papers 34; pp. 422-36.

Eaton, J. [1987], "Public Debt Guarantees and Private Capital Flight," World Bank Economic Review 1; pp. 377-95.

Edwards, S. [1991], "Capital Flows, Foreign Direct Investment, and DebtEquity Swaps in Developing Countries," in Horst Siebert (ed.), Capital Flows in the World Economy, Tubingen: J.C.B. Mohr.

Gertler, M. and Rogoff, K. [1990], "North-South Lending and Endogenous Domestic Capital Market Inefficiencies," Journal of Monetary Economics 26; pp. 245-66.

International Monetary Fund [1995], Balance of Statistics Yearbook, Washington, D.C.

International Monetary Fund [1995], International Financial Statistics Yearbook, Washington, D.C.

Kant, C. [1996], Foreign Direct Investment and Capital Flight, Princeton Studies in International Finance, No. 80, April, 1996.

Kuczynski, P. [1992], "International Capital Flows into Latin America: What is the Promise?" in Lawrence H. Summers and Anwar M. Shah, (eds.) Proceedings of the World Bank Annual Conference on Development Economics, Washington, D.C.

Lessard, D. R. \& Williamson, J. eds. [1987], Capital Flight and Third World Debt, Institute for International Economics, Washington, D.C.

Pastor, M., Jr. [1990], Capital Flight from Latin America, World Development 18; pp. 1-18. 
Swoboda, A. K. [1983], "Exchange Rate Regimes and U.S.-European Policy Interdependence," IMF Staff Papers 30; pp. 75-102.

United Nations Conference on Trade and Development [1994], World Investment Report, New York, 1994.

World Bank [1994], Capital Flight Estimates (computer diskette), International Economics Department, The World Bank, Washington, D.C.

World Bank [1995], World Debt Tables, Washington, D.C. 